\title{
Zeolite and Active Carbon Addition on Closed System Transportation for Milkfish Juvenile (Chanos chanos) Survival Rate
}

\author{
Mustahal*, Forcep Rio Indaryanto, Deri Hermawan, and Mas Bayu Syamsunarno \\ Department of Fisheries, Faculty of Agriculture, University of Sultan Ageng Tirtayasa, Indonesia \\ * Corresponding author.Email:mustahal13@gmail.com
}

Abstract - The purpose of this study was to determine the effectiveness of the optimum ratio of zeolite and activated carbon to preserve the survival rate of milkfish juvenile in closed system transportation. This research was conduct from May to July 2018 at the Laboratory of Aquaculture, University of Sultan Ageng Tirtayasa. The research design uses a completely randomized design (CRD) with 6 treatments and 3 replications, i.e. P1) without zeolite and activated carbon; P2) zeolite 20 g; P3) zeolite $15 \mathrm{~g}$ and activated carbon $5 \mathrm{~g}$; P4) zeolite $10 \mathrm{~g}$ and activated carbon $10 \mathrm{~g}$; P5) zeolite $5 \mathrm{~g}$ and activated carbon $15 \mathrm{~g}$; P6) activated carbon $20 \mathrm{~g}$. The fish size used was $2.2 \pm 0.56 \mathrm{~cm}$ with a density of 250 fish per 1.3 liters of water. The best results were the treatment of zeolite $15 \mathrm{~g}$ and activated carbon 5 g. Optimal transport time was 36 hours with an average survival rate is $91 \%$, but it was still suitable for up to 48 hours with an average survival rate was $80 \%$.

Keywords: active carbon, milkfish, transportation, zeolite

\section{INTRODUCTION}

Milkfish is a brackish water fish that has a specific taste. This fish has become a superior commodity and its processing has become the province's special food. Banten people prefer buying milkfish compared to other types of fish or with a preference of $45.1 \%$ [1], milkfish satay or sate bandeng are the Banten province's special food. Nutritional composition per 100 grams of milkfish meat is $129 \mathrm{kcal}$ energy, 20 gr protein, $4.8 \mathrm{~g}$ fat, $20 \mathrm{mg}$ calcium, $150 \mathrm{mg}$ phosphorus, $2 \mathrm{mg}$ iron, $150 \mathrm{IU}$ vitamin A and $0.05 \mathrm{mg}$ vitamin B1 [2].

At present, milkfish juvenile still obtained from nature. Fish farmers in Banten province generally obtain juvenile from fish hatcheries in Gondol, Singaraja, Bali Province. The problem of milkfish farmers is low survival rates, because of the distance and the length of time in juvenile transporting. The closed system transportation is more profitable, efficiency in the use of places, transporting more fish and can be transported over long distances. In this system, the factors that cause fish mortality are reduced dissolved oxygen, high temperatures, high-stress levels, and toxic 
metabolites such as ammonia and $\mathrm{CO}$ accumulation, respectively [3]. Furthermore, the purpose of fish transportation will be achieved if it is successful in overcoming environmental changes and reducing mortality [4]. The expected survival rate is more than $90 \%$. The way to neutralize ammonia or the total concentration of ammonia nitrogen (TAN) is by adding zeolite and activated carbon in the packing media.

The studies about closed system transportation using zeolite and activated carbon has been done previously in several types of fish, such as Pangasionodon hyppophthalmus [3], and Corydoras aenus [5]. Both of these studies prove that zeolite can reduce the increase in total ammonia nitrogen. The purpose of this study was to Table 1. The survival rate of milkfish juvenile in closed system transportation

\begin{tabular}{|c|c|c|c|c|c|}
\hline \multirow{2}{*}{ Treatments } & \multicolumn{5}{|c|}{ Hours } \\
\hline & 0 & 12 & 24 & 36 & 48 \\
\hline P1) control & 100 & $97.5^{\mathrm{a}}$ & $90.3^{\mathrm{a}}$ & $82.8^{\mathrm{a}}$ & $68.0^{\mathrm{a}}$ \\
\hline P2) zeolite $20 \mathrm{~g}$ & 100 & $99.2^{b}$ & $96.0^{\mathrm{b}}$ & $89.3^{\mathrm{ab}}$ & $78.0^{\mathrm{ab}}$ \\
\hline P3) zeolite $15 \mathrm{~g}+$ activated carbon $5 \mathrm{~g}$ & 100 & $99.7^{\mathrm{b}}$ & $96.9^{b}$ & $91.1^{b}$ & $80.0^{b}$ \\
\hline P4) zeolite $10 \mathrm{~g}+$ activated carbon $10 \mathrm{~g}$ & 100 & $99.5^{\mathrm{b}}$ & $95.2^{\mathrm{b}}$ & $88.8^{\mathrm{ab}}$ & $76.0^{\mathrm{ab}}$ \\
\hline P5) zeolite $5 \mathrm{~g}+$ activated carbon $15 \mathrm{~g}$ & 100 & $99.2^{b}$ & $95.2^{\mathrm{b}}$ & $86.0^{\mathrm{ab}}$ & $74.0^{\mathrm{ab}}$ \\
\hline P6) activated carbon $20 \mathrm{~g}$ & 100 & $99.6^{\mathrm{b}}$ & $97.5^{\mathrm{b}}$ & $90.8^{\mathrm{b}}$ & $72.0^{\mathrm{ab}}$ \\
\hline
\end{tabular}

The fish size used was $2.2 \pm 0.56 \mathrm{~cm}$ with a density of 250 fish per 1.3 liters of water. The survival rate is a percentage of the comparison value between the number of fish that live to the end of packing and the

\section{RESULTS AND DISCUSSION}

The results of survival rate are shown in Table 1 while the total concentration of determine the effectiveness of the optimum ratio of zeolite and activated carbon to preserve the survival rate of milkfish juvenile in closed system transportation.

\section{METHODS}

This research has been conducted from May to July 2018 at the Laboratory of Aquaculture, University of Sultan Ageng Tirtayasa. The research design used a completely randomized design (CRD) with 6 treatments and 3 replications, i.e. P1) without zeolite and activated carbon; P2) zeolite $20 \mathrm{~g}$; P3) zeolite $15 \mathrm{~g}$ and activated carbon $5 \mathrm{~g}$; P4) zeolite $10 \mathrm{~g}$ and activated carbon $10 \mathrm{~g}$; P5) zeolite $5 \mathrm{~g}$ and activated carbon $15 \mathrm{~g}$; P6) activated carbon $20 \mathrm{~g}$. 
juvenile for 48 hours are $\mathrm{P} 3$ or zeolite $15 \mathrm{~g}$ and activated carbon $5 \mathrm{~g}$ with average survival rate is $80 \%$. This survival rate is not optimal results because the expected survival rate is more than $90 \%$., the optimal transport time is 36 hours with an average survival rate is $91.1 \%$. In transport time 36 hours, P3 and P6 are not significantly different, but zeolite has a cheaper price, so the use of zeolite $10 \mathrm{~g}$ and $5 \mathrm{~g}$ of activated carbon is more effective and efficient.
According to Ahmad and Yakob [8], milkfish is a fishery commodity that is resistant to environmental changes, and they suggested that the transport of juveniles from the hatchery to the pond is not more than 12 hours. It can be seen in the results of transportation without treatment (P1) that the transport time of 12 hours gives the best results, but it is still feasible to transport the milkfish juvenile for 24 hours.

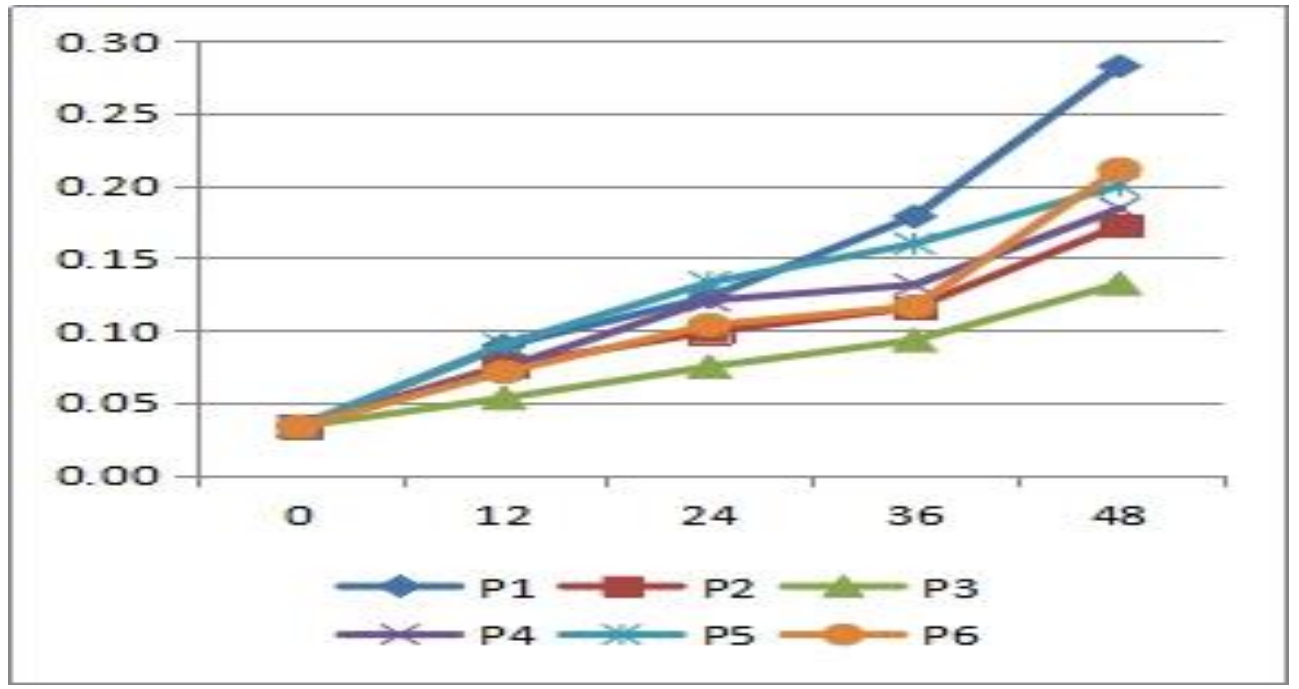

Figure 1. Total concentration of ammonia nitrogen (TAN)

Overall, TAN during transportation has increased. Nitrogen compounds are the main element in metabolic waste products, the most of which are urea and ammonia [9]. The combination of Zeolite and activated carbon has been shown to reduce the increase in total concentration of ammonia nitrogen (Figure 1).

Mortality in the transportation of fish juveniles is caused by ammonia that exceeds the fish tolerance limit. High ammonia content will affect the permeability of fish to water and reduce the concentration of ions in the body, thereby increasing tissue oxygen consumption and causing gill damage and reducing blood capacity in oxygen transport [10]. Effendi [11], claims that ammonia is harmful to fish at a concentration of $0.2 \mathrm{mg} / \ell$. It's proven in $(\mathrm{P} 1),(\mathrm{P} 5)$ and (P6) that the TAN value is close to or more than $0.2 \mathrm{mg} / \ell$ has a low survival rate. 


\section{CONCLUSION}

It can be concluded that the treatment of zeolite $15 \mathrm{~g}$ and activated carbon $5 \mathrm{~g}$. with the optimal transportation time at 36 hours was

\section{ACKNOWLEDGEMENT}

This study funded by an internal research grant in Faculty of Agriculture. Thanks to

\section{REFERENCES}

[1] F.R. Indaryanto and Saifullah, "Analysis of Consumer Preference on Fish Purchases at Rau and Lama Market, Serang City, Banten," Jurnal Penelitian Ilmu-Ilmu Sosial dan Eksakta, vol. 22, no. 3, pp. 56-65, 2011.

[2] S. Fauzi, Profile of Milkfish Commodities, Warta Pasar Ikan KKP http://wpi.kkp.go.id/?q=node/46, Accessed 05 Oct 2018.

[3] E. Supriyono, R. Syahputra, M.F.R. Ghozali, D. Wahjuningrum, K. Nirmala and A.H. Kristanto, "Effectivity of utilization of zeolite, activated charcoal, and clove oil to cortisol hormone on the high-density transportation system of juvenile of Pangasionodon hyppophthalmus," Jurnal Ikhtiologi Indonesia, vol. 11, no. 1, pp. $67-75,2011$.

[4] M. Huet, Text Book of Fish Culture: Breeding and Cultivation of Fish, London: Fishing News. p. 405, 1971.

[5] E. Supriyono, A. Supendi and K. Nirmala, "The Use of Zeolit and Activated Carbon on Packing System of Corydoras aenus," Jurnal Akuakultur Indonesia, vol. 6, no. 2, doi: 10.19027/jai.6.135-145, 2007. able to yield the average survival rate of $91 \%$, however, with transportation time up to 48 hours the average survival rate was $80 \%$.

Mina Mandiri fish cultivator group, Pontang Subdistrict, Serang Regency, Banten Province who have facilitated this research.

[6] M.I. Effendi, Fisheries Biology, $2^{\text {nd }}$ ed., Yogyakarta: Yayasan Pustaka Nusantara, p. 163, 2002.

[7] [NSAI] The National Standardization Agency of Indonesia, Water and waste water - Part 30: Test methods of the ammonia content with spectro photometers by phenates (SNI 066989.30-2005), Jakarta: The National Standardization Agency of Indonesia, 2005.

[8] T. Ahmad and M.J.R. Yakob, "Intensive Culture of Milkfish in the fishpond," The Final Progress of Coastal Aquaculture Technology to Support National Economic Recovery, p. 243, 1998 [Proceedings of the Seminar on Coastal Fisheries Technology, Bali, 6-7 Agustus 1998].

[9] K.P. Anwar, S. Suharto, and A. Syarifuddin, "Prospects for the Use of Zeolites as NH4+ Absorbers in Wastewater," unpublished, 1998.

[10] C.E. Boyd, Water Quality in Pond for Aquaculture, Birmingham: Birmingham Publ. Co, 1990.

[11] H. Effendi, Review of Water Quality for Resource Management and Aquatic Environment, Yogyakarta : ,258p. 2003 